\title{
Formation process of recent fumarolic gases at the Mt. Mihara summit peak of the Izu-Oshima volcano, Japan
}

\author{
Takeshi Ohba \\ Volcanic Fluid Research Center, Tokyo Institute of Technology, 2-12-1 Ookayama, Meguro, Tokyo 152-8551, Japan
}

(Received August 5, 2007; Revised September 15, 2007; Accepted September 18, 2007; Online published October 19, 2007)

\begin{abstract}
We have investigated the chemical and isotopic composition of recently formed gases emitted by three fumaroles on the Mt. Mihara summit peak of the Izu-Oshima volcano in order to assess the formation process of these gases. The $\mathrm{CO}_{2} / \mathrm{H}_{2} \mathrm{O}$ ratio of these gases varied greatly, with the $\delta \mathrm{D}$ and $\delta^{18} \mathrm{O}$ of the $\mathrm{H}_{2} \mathrm{O}$ being as low as a vapor phase equilibrated with the local meteoric water. These features are explained by a mixing of the vapor equilibrated with local meteoric groundwater and primary steam, which is a vapor phase generated by the mixing of magmatic gas and a cold meteoric groundwater. We concluded that there was no direct mixing between the magmatic vapor and a vapor phase of meteoric origin in the processes involved in fumarolic gas formation.
\end{abstract}

Key words: Fumarolic gases, formation process, Izu-Oshima volcano, $\mathrm{CO}_{2} / \mathrm{H}_{2} \mathrm{O}$ ratio, $\delta \mathrm{D}$ and $\delta^{18} \mathrm{O}$ values.

\section{Introduction}

Izu-Oshima is an insular volcano located in the Pacific Ocean (Fig. 1) which has shown intermittent eruptive activities. In 1986, a sequence of eruptions occurred, the magnitude of which was relatively large compared to those of previous eruptions (Fuji et al., 1988; Kawanabe, 1998). The 1986 eruptions produced lava flows on the northern west flank of the volcano, near the residential area of the island, necessitating that all residents of the island (up to 10,000) be evacuated. It is therefore necessary to assess the danger posed by this volcano by monitoring its activity with the aim of predicting future eruptions and thereby mitigating its threat to the residents of the island.

In general, the flux of magmatic $\mathrm{CO}_{2}$ is expected to increase prior to the eruption, if the eruption is due to the ascent of magma (Notsu et al., 2006). Suwa and Tanaka (1959) found a pre-eruptive increase in the temperature of fumarolic gases at Mt. Mihara, which is the summit peak of the Izu-Oshima volcano. According to Shimoike and Notsu (2000), the $\mathrm{CO}_{2}$ concentration in steam, which is discharged at the bore hole drilled on the northern flank of volcano, gradually decreased after the eruption in 1986, although there are annual fluctuations. The ${ }^{3} \mathrm{He} /{ }^{4} \mathrm{He}$ ratio in the steam started to increase immediately after the eruption in 1986, reaching a maximum in later in 1986, before it decreased gradually (Sano et al., 1995). These observations suggest that the temperature of fumarolic gases and the chemical composition of volcanic fluid are intimately related to the activity of the Izu-Ohsima volcano.

Kazahaya et al. (1993) sampled and analyzed the fumarolic gases produced between 1988 and 1991 at Mt. Mihara. Their analyses of the hydrogen and oxygen isotopes

Copyright (c) The Society of Geomagnetism and Earth, Planetary and Space Sciences (SGEPSS); The Seismological Society of Japan; The Volcanological Society of Japan; The Geodetic Society of Japan; The Japanese Society for Planetary Sciences; TERRAPUB. revealed that the fumarolic gases were a mixture of magmatic vapor, meteoric water, and sea water. In 1988, the magmatic vapor comprised $70 \%$ fumarolic gases; this decreased to $40 \%$ in 1989 , assuming that the $\delta \mathrm{D}$ and $\delta^{18} \mathrm{O}$ of magmatic water was -27 and $+5.3 \%$, respectively. The isotope ratio and chemical composition of fumarolic gases has not been assessed since 1989. The aim of this study, therefore, was to sample recently produced fumarolic gases in order to estimate the process of gas discharge formation at Mt. Mihara.

\section{Sampling and Analysis of Fumarolic Gases}

Fumarolic gases were sampled between 2004 and 2007 at the three fumaroles, Kengamine (K), A, and X-15, located on Mt. Mihara (Fig. 2). The flux of gases was largest at Kengamine $(\mathrm{K})$, where the plume visible at a distance of $2 \mathrm{~km}$, and the smallest at fumarole A, where it was difficult to recognize the plume at a distance of $200 \mathrm{~m}$. The discharge of gases at X-15 was more active than that at $\mathrm{A}$. The outlet temperature of the gases at X-15 has been monitored by the Japan Meteorological Agency (JMA).

The temperature of all fumarolic gases was less than $80^{\circ} \mathrm{C}$. As all of the gases contained air, which prevented the use of normal sampling methods for fumarolic gas, such as those of Ozawa (1968) and Giggenbach (1975), we used the apparatus shown in Fig. 3(a) for the chemical analysis. Fumarolic gases were first washed with $20 \mathrm{ml}$ of $5 \mathrm{M} \mathrm{KOH}$ solution contained in an impinger, which was warmed with hot water to prompt the absorption of $\mathrm{CO}_{2}$ by the $\mathrm{KOH}$ solution. A similar sampling method was employed by Taran et al. (2001) to sample a gas contaminated with air at the Colima volcano. The end of the sampling train was aspirated by a calibrated $100-\mathrm{ml}$ glass syringe. The accumulated volume of aspirated gas was recorded. A desiccant tube containing $\mathrm{CaCl}_{2}$ powder was attached to the end of the impinger to capture the water vapor released from the $\mathrm{KOH}$ solution. The other end of the desiccant tube was attached to a glass 


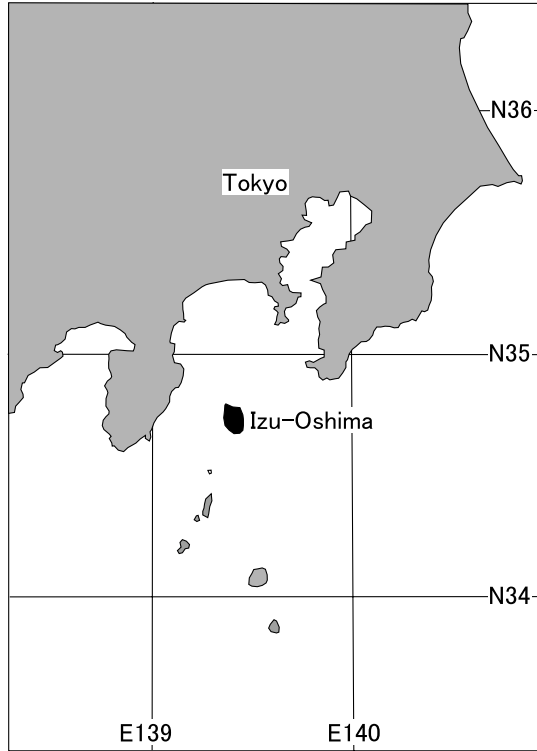

Fig. 1. The location of Izu-Oshima island.

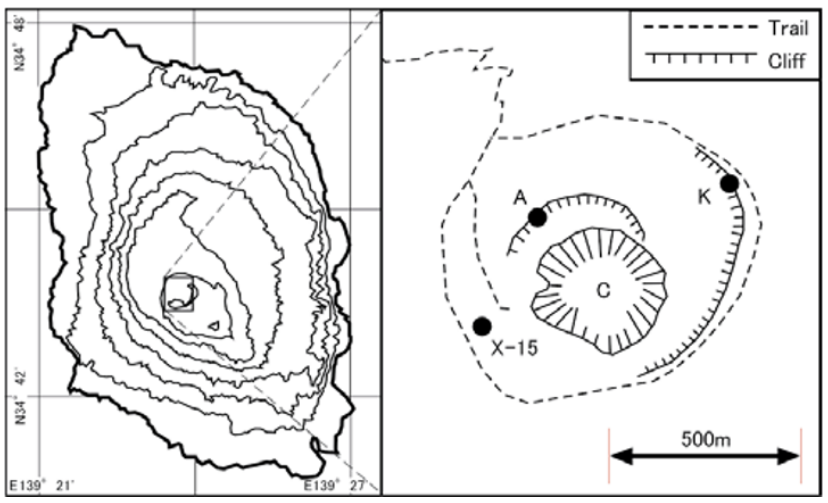

Fig. 2. Left Topography of the Izu-Oshima volcano with contours at 100-m intervals. Right The location of fumarolic gases emitted from fumaroles K, X-15, and A on Mt. Mihara.

tube with cocks to sample gases not absorbed by the $\mathrm{KOH}$ solution. There was no smell of $\mathrm{H}_{2} \mathrm{~S}$ and $\mathrm{SO}_{2}$ at the fumaroles, and the absence of those gases was confirmed at the outlet of fumaroles by GASTEC detector tubes.

The sum of the weight of the impinger and the desiccant tube was determined before and after the sampling of the gas, and the weight increment was attributed to the sum of $\mathrm{H}_{2} \mathrm{O}$ and $\mathrm{CO}_{2}$ in the fumarolic gases. The air sampled in the glass tube was analyzed by a gas chromatograph with $\mathrm{Ar}$ carrier gas. The $\mathrm{KOH}$ solution in the impinger was made up to $100 \mathrm{ml}$ with pure water. The amount of absorbed $\mathrm{CO}_{2}$ in $\mathrm{KOH}$ was determined by micro-diffusion analysis (Conway, 1950). We did not analyze the sample for sulfur content because the absence of sulfur-bearing gases had been confirmed at the sampling site.

A condenser (Fig. 3(b)) was used to obtain the sample for the stable isotope analysis of $\mathrm{H}_{2} \mathrm{O}$ vapor in fumarolic gas. A rolled rubber tube was immersed in water chilled with ice, and the fumarolic gas was passed through the tube. The condensed $\mathrm{H}_{2} \mathrm{O}$ vapor was collected in a small glass bottle attached to one end of the chilled rubber tube. The collected
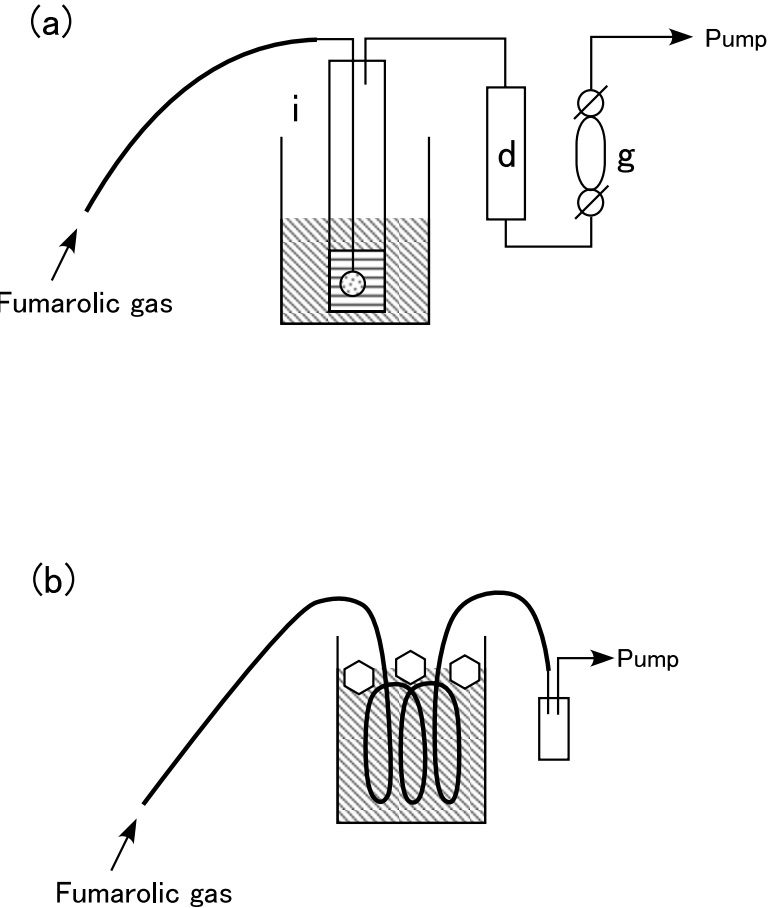

Fig. 3. Apparatus used for fumarolic gas sampling. The sampling trains in (a) and (b) were used for analyzing the chemical composition of gases and the stable isotopes, respectively. The $\mathrm{i}, \mathrm{d}$, and $\mathrm{g}$ in (a) is the impinger warmed with hot water, the desiccant tube, and the glass tube, respectively.

condensate was reduced to $\mathrm{H}_{2}$ gas with metallic $\mathrm{Zn}$ (Coleman et al., 1982). The $\mathrm{H}_{2}$ gas so produced was subjected to stable isotope measurement on a MAT-252 mass spectrometer. The collected condensate was also equilibrated with $\mathrm{CO}_{2}$ gas (Epstein and Mayeda, 1953) for the measurement of $\delta^{18} \mathrm{O}$ on the MAT-252.

In order to measure $\delta^{13} \mathrm{C}$ of $\mathrm{CO}_{2}$ in the fumarolic gas, the gas was introduced into a $50-\mathrm{ml}$ plastic syringe containing $10 \mathrm{ml}$ of saturated $\mathrm{Ba}(\mathrm{OH})_{2}$ solution. Once the fumarolic gas was in the syringe, a valve attached to the inlet of the syringe was closed, and the syringe was shaken vigorously to confirm the fixation of $\mathrm{CO}_{2}$ gas as a $\mathrm{BaCO}_{3}$ precipitate. The gas phase left in the syringe was discarded after shaking. The above procedure was repeated about 20 times to collect enough $\mathrm{BaCO}_{3}$ precipitate for analysis. The collected precipitate of $\mathrm{BaCO}_{3}$ was allowed to react with $\mathrm{H}_{3} \mathrm{PO}_{4}$ in vacuum to obtain pure $\mathrm{CO}_{2}$ gas. The $\delta^{13} \mathrm{C}$ of the prepared $\mathrm{CO}_{2}$ gas was measured on the MAT-252.

\section{Results}

The outlet temperature, chemical composition, and isotope ratio of fumarolic gas are listed in Table 1. The collected fumarolic gas is a mixture of $\mathrm{H}_{2} \mathrm{O}$ vapor, $\mathrm{CO}_{2}$, $\mathrm{H}_{2}$, and air. The outlet temperatures at $\mathrm{K}, \mathrm{X}-15$, and $\mathrm{A}$ were stable at $77-78,65-66$, and $57-58^{\circ} \mathrm{C}$, respectively. The $\mathrm{CO}_{2} / \mathrm{H}_{2} \mathrm{O}$ ratio of gas at $\mathrm{K}$ was $0.0287-0.0297$, which is much higher than that of the gas at $\mathrm{X}-15$, which was 0.0063-0.00148. The $\mathrm{CO}_{2} / \mathrm{H}_{2} \mathrm{O}$ ratio of gas at $\mathrm{A}$ was $0.0147-0.0250$, which is slightly lower than the ratio of gas at $\mathrm{K}$. The isotope ratio of $\mathrm{H}_{2} \mathrm{O}$ in the fumarolic gas at $\mathrm{K}$ and $\mathrm{X}-15$ was -74 to $-67 \%$ for $\delta \mathrm{D}$ and -12.5 to $-10.8 \%$ o 
Table 1. Chemical and isotopic composition of fumarolic gases at Izu-Oshima volcano.

\begin{tabular}{|c|c|c|c|c|c|c|c|c|c|c|}
\hline \multirow[t]{2}{*}{ Location } & \multirow[t]{2}{*}{ Date } & \multirow{2}{*}{$\begin{array}{l}\text { Temp. } \\
\left({ }^{\circ} \mathrm{C}\right)\end{array}$} & \multicolumn{3}{|c|}{ Gases excluding air } & \multirow[b]{2}{*}{$\begin{array}{l}\mathrm{CO}_{2} / \mathrm{H}_{2} \mathrm{O} \\
\text { molar ratio }\end{array}$} & \multirow{2}{*}{$\begin{array}{c}\text { Air } \\
\text { molar } \%\end{array}$} & \multicolumn{2}{|c|}{$\mathrm{H}_{2} \mathrm{O}$} & \multirow{2}{*}{$\begin{array}{c}\mathrm{CO}_{2} \\
\delta^{13} \mathrm{C}_{\mathrm{PDB}} \\
(\% \circ)\end{array}$} \\
\hline & & & $\begin{array}{c}\mathrm{H}_{2} \mathrm{O} \\
\mathrm{mmol} / \mathrm{mol}\end{array}$ & $\begin{array}{c}\mathrm{CO}_{2} \\
\mathrm{mmol} / \mathrm{mol}\end{array}$ & $\begin{array}{c}\mathrm{H}_{2} \\
\mathrm{mmol} / \mathrm{mol}\end{array}$ & & & $\begin{array}{c}\delta \mathrm{D}_{\text {SMOW }} \\
(\% \circ)\end{array}$ & $\begin{array}{c}\delta^{18} \mathrm{O}_{\text {SMOW }} \\
(\% \circ)\end{array}$ & \\
\hline $\mathrm{K}$ & $2006 / 3 / 29$ & 77.3 & 971.1 & 28.8 & 0.015 & 0.0297 & 52.9 & -69 & -11.0 & -3.7 \\
\hline $\mathrm{K}$ & $2007 / 4 / 2$ & 78.5 & 972.1 & 27.9 & 0.0059 & 0.0287 & 55.4 & -67 & -10.8 & -3.1 \\
\hline$X-15$ & $2004 / 3 / 9$ & 65.0 & 991.3 & 8.7 & na & 0.0087 & 80.5 & -71 & -11.8 & na \\
\hline$X-15$ & $2005 / 11 / 16$ & 66.5 & 993.7 & 6.3 & na & 0.0063 & 80.2 & -74 & -12.5 & na \\
\hline$X-15$ & $2006 / 3 / 29$ & 66.2 & 985.4 & 14.6 & 0.0012 & 0.0148 & 83.2 & -74 & -11.8 & na \\
\hline $\mathrm{X}-15$ & $2007 / 4 / 2$ & 65.9 & 987.4 & 12.6 & 0.00054 & 0.0128 & 83.9 & -72 & -11.8 & na \\
\hline A & $2004 / 3 / 10$ & 56.0 & 975.6 & 24.4 & na & 0.0250 & 86.3 & -91 & -15.2 & na \\
\hline A & $2005 / 11 / 16$ & 57.4 & 985.6 & 14.4 & na & 0.0147 & 85.6 & -91 & -15.0 & na \\
\hline
\end{tabular}

na: not analyzed

for $\delta^{18} \mathrm{O}$. The $\delta \mathrm{D}$ and $\delta^{18} \mathrm{O}$ values of $\mathrm{H}_{2} \mathrm{O}$ at $\mathrm{A}$ were much lower than those at $\mathrm{K}$ and $\mathrm{X}-15$. The $\delta^{13} \mathrm{C}$ of $\mathrm{CO}_{2}$ in the gas at $\mathrm{K}$ was -3.7 to $-3.1 \%$, which is the value characteristic of $\mathrm{H}_{2} \mathrm{O}$ of arc volcanic origin (Sano and Marty, 1995). The concentration of $\mathrm{CO}_{2}$ in gas from X-15 and $\mathrm{A}$ was too low to collect enough $\mathrm{BaCO}_{3}$ precipitate for isotope analysis. Although the level of $\mathrm{H}_{2}$ in the gases from the three fumaroles varied greatly, the concentration of $\mathrm{H}_{2}$ in the gas at $\mathrm{K}$ was almost tenfold higher than that in the gas at X-15.

\section{Discussion}

\subsection{Condensation of water vapor}

The correlation between the $\delta \mathrm{D}$ and $\delta^{18} \mathrm{O}$ of $\mathrm{H}_{2} \mathrm{O}$ in fumarolic gas is shown in Fig. 4, where the local meteoric water (MW) at the Izu-Ohsima volcano (Takahashi et al., 2000), magmatic vapor (MV) characteristic of the subduction zone (Taran et al., 1990; Giggenbach, 1992), and sea water (SW) are also plotted. The $\mathrm{H}_{2} \mathrm{O}$ sampled by Kazahaya et al. (1993) in 1988-1991 plots within the triangle defined by MW, MV, and SW, suggesting that the $\mathrm{H}_{2} \mathrm{O}$ was a mixture of those three end members. Izu-Oshima is an insular volcano. The section of the island lower than sea water level could be invaded by sea water. According to Kazahaya et al. (1993), cracks would have developed around the conduit beneath the crater after the eruption in 1986. Sea water could have been transported through these cracks to the conduit, resulting in the volcanic gas being contaminated with sea water. In December 1989, the isotope ratio of the fumarolic gas emitting from the fumaroles showed little contamination by sea water. This change was explained by Kazahaya et al. (1993) to be the result of crack closure.

The isotope ratio observed in this study was much lower than the $\mathrm{H}_{2} \mathrm{O}$ reported by Kazahaya et al. (1993). Such a low isotope ratio might be explained by a partial condensation of $\mathrm{H}_{2} \mathrm{O}$ vapor as condensation reduces the isotope ratios of the remaining $\mathrm{H}_{2} \mathrm{O}$ vapor. This process is modeled by the Rayleigh fractionation process, expressed by,

$$
\delta=\left(\delta_{i}+1000\right) F^{\alpha-1}-1000,
$$

where $\delta$ indicates the delta notation of $\mathrm{D} / \mathrm{H}$ or ${ }^{18} \mathrm{O} /{ }^{16} \mathrm{O}$ of $\mathrm{H}_{2} \mathrm{O}$, subscript $i$ indicates the state of the $\mathrm{H}_{2} \mathrm{O}$ vapor prior to condensation, $F$ indicates the fraction of $\mathrm{H}_{2} \mathrm{O}$ vapor left after condensation, and $\alpha$ is the isotope fractionation factor between liquid water and vapor, the numerical value of which is listed in Table 2. The lines C1, C2, and C3 in

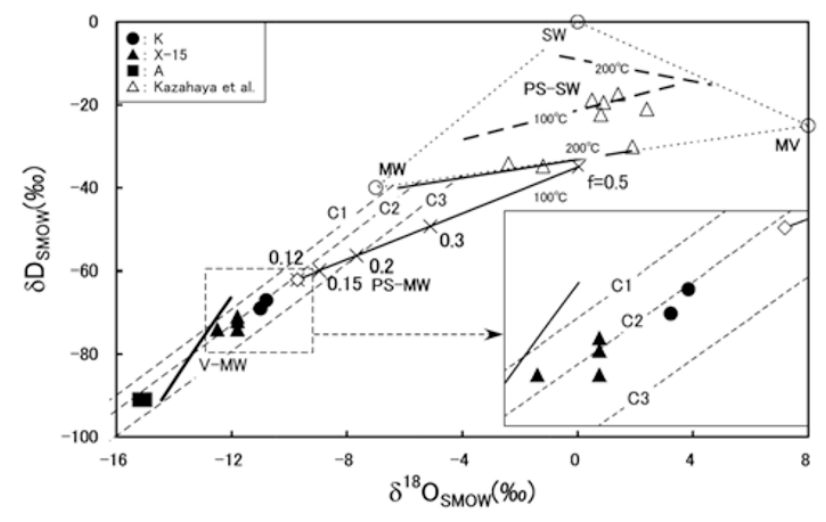

Fig. 4. Correlation between $\delta \mathrm{D}$ and $\delta^{18} \mathrm{O}$ of $\mathrm{H}_{2} \mathrm{O}$ in fumarolic gas with calculated primary steam and the end members producing the primary steam. The solid circle, solid triangle, and solid rectangle indicate the fumarolic gas at the $\mathrm{K}, \mathrm{X}-15$, and $\mathrm{A}$, fumaroles, respectively. Open triangles indicate the fumarolic gas analyzed in 1988-1989 by Kazahaya et al. (1993). MV, MW, and SW are the magmatic vapor, local meteoric water, and sea water, respectively. The solid line denoted by PS-MW represents the primary steam at 100 and $200^{\circ} \mathrm{C}$, allowing the freedom in the mixing fraction of MV. The dashed line denoted by PS-SW represents the primary steam at 100 and $200^{\circ} \mathrm{C}$ generated from the MV and SW. The solid line denoted by $\mathrm{V}-\mathrm{MW}$ is a $\mathrm{H}_{2} \mathrm{O}$ vapor equilibrated with $\mathrm{MW}$ at $50-100^{\circ} \mathrm{C}$. The dotted lines denoted by $\mathrm{C} 1, \mathrm{C} 2$, and $\mathrm{C} 3$ indicate the trajectory of remained $\mathrm{H}_{2} \mathrm{O}$ vapor left after the partial condensation of $\mathrm{H}_{2} \mathrm{O}$ vapor. The starting stage of condensation was assumed to be located on the mixing line connecting MV and MW. The mixing fraction of $\mathrm{MV}$ in $\mathrm{C} 1, \mathrm{C} 2$, and $\mathrm{C} 3$ is 4,10 , and $20 \%$, respectively. The diamond symbol indicates the potential end member of PS-MW to form fumarolic gases at $\mathrm{K}$ and $\mathrm{X}-15$.

Fig. 4 indicate the change in the isotope ratio of the $\mathrm{H}_{2} \mathrm{O}$ vapor where the fraction of condensation was allowed to be variable. The condensation was assumed to take place at $100^{\circ} \mathrm{C}$. The isotope ratio of the $\mathrm{H}_{2} \mathrm{O}$ vapor decreases during the process of condensation. The initial $\mathrm{H}_{2} \mathrm{O}$ vapor before the start of condensation was assumed to be a mixture of MW and MV. Under the above assumption, C1, C2, and C3 comprise 4, 10, and 20\% MV, respectively. The gases at $\mathrm{K}$ and X-15 are plotted along the line C2 (insert in Fig. 4).

The process of fumarolic gas formation could be analyzed more confidently by introducing the $\mathrm{CO}_{2} / \mathrm{H}_{2} \mathrm{O}$ ratio in the gas with the $\delta \mathrm{D}$ and $\delta^{18} \mathrm{O}$ (Sawa et al., 2006). In Fig. 5, the $\delta^{18} \mathrm{O}$ of $\mathrm{H}_{2} \mathrm{O}$ is correlated with the $\mathrm{CO}_{2} / \mathrm{H}_{2} \mathrm{O}$ ratio of the fumarolic gas. Because the concentration of carbonate and bicarbonate ions in MW and SW is low, even if MV 
Table 2. Parameters used for the calculatioin on the composition of primary steam.

\begin{tabular}{|c|c|c|c|c|}
\hline Term & & Symbol & Value & Unit \\
\hline Temperature of MV & & & 1100 & ${ }^{\circ} \mathrm{C}$ \\
\hline Temperature of MW & & & 18 & ${ }^{\circ} \mathrm{C}$ \\
\hline Enthalpy of MV & & $H_{\mathrm{MV}}$ & 4875 & $\mathrm{~kJ} / \mathrm{kg}$ \\
\hline Enthalpy of MW & & $H_{\mathrm{MW}}$ & 75 & $\mathrm{~kJ} / \mathrm{kg}$ \\
\hline Enthalpy of PS & at $100^{\circ} \mathrm{C}$ & $H_{\mathrm{PS}}$ & 2677 & $\mathrm{~kJ} / \mathrm{kg}$ \\
\hline Enthalpy of PW & at $100^{\circ} \mathrm{C}$ & $H_{\mathrm{PW}}$ & 417 & $\mathrm{~kJ} / \mathrm{kg}$ \\
\hline Enthalpy of PS & at $200^{\circ} \mathrm{C}$ & $H_{\mathrm{PS}}$ & 2792 & $\mathrm{~kJ} / \mathrm{kg}$ \\
\hline Enthalpy of PW & at $200^{\circ} \mathrm{C}$ & $H_{\mathrm{PW}}$ & 855 & $\mathrm{~kJ} / \mathrm{kg}$ \\
\hline$\delta \mathrm{D}$ of $\mathrm{MV}$ & & $\delta_{\mathrm{MV}}$ & -25 & $\%$ \\
\hline$\delta \mathrm{D}$ of $\mathrm{MW}$ & & $\delta_{\mathrm{MW}}$ & -40 & $\% o$ \\
\hline$\delta \mathrm{D}$ of $\mathrm{SW}$ & & $\delta_{\mathrm{SW}}$ & 0 & $\%$ \\
\hline$\delta^{18} \mathrm{O}$ of $\mathrm{MV}$ & & $\delta_{\mathrm{MV}}$ & 8 & $\%$ \\
\hline$\delta^{18} \mathrm{O}$ of $\mathrm{MW}$ & & $\delta_{\mathrm{MW}}$ & -7 & $\%$ \\
\hline$\delta^{18} \mathrm{O}$ of SW & & $\delta_{\mathrm{SW}}$ & 0 & $\%$ \\
\hline $\mathrm{CO}_{2} / \mathrm{H}_{2} \mathrm{O}$ of $\mathrm{MV}$ & & $C_{\mathrm{MV}}$ & 0.04 & \\
\hline $\mathrm{CO}_{2} / \mathrm{H}_{2} \mathrm{O}$ of $\mathrm{MW}$ & & $C_{\mathrm{MW}}$ & 0 & \\
\hline $\mathrm{CO}_{2} / \mathrm{H}_{2} \mathrm{O}$ of $\mathrm{SW}$ & & $C_{\mathrm{SW}}$ & 0 & \\
\hline $\mathrm{D} / \mathrm{H}$ fractionation factor & at $100^{\circ} \mathrm{C}$ & $\alpha$ & 1.0283 & \\
\hline${ }^{18} \mathrm{O} /{ }^{16} \mathrm{O}$ fractionation factor & at $100^{\circ} \mathrm{C}$ & $\alpha$ & 1.00509 & \\
\hline $\mathrm{CO}_{2} / \mathrm{H}_{2} \mathrm{O}$ distribution coefficient & at $100^{\circ} \mathrm{C}$ & $\beta$ & 0.000215 & \\
\hline $\mathrm{D} / \mathrm{H}$ fractionation factor & at $200^{\circ} \mathrm{C}$ & $\alpha$ & 1.00237 & \\
\hline${ }^{18} \mathrm{O} /{ }^{16} \mathrm{O}$ fractionation factor & at $200^{\circ} \mathrm{C}$ & $\alpha$ & 1.00341 & \\
\hline $\mathrm{CO}_{2} / \mathrm{H}_{2} \mathrm{O}$ distribution coefficient & at $200^{\circ} \mathrm{C}$ & $\beta$ & 0.00266 & \\
\hline
\end{tabular}

The value of $\alpha$ was given by Horita and Wesolowski (1994). The value of $\beta$ was given by Giggenbach (1980). The value of enthalpy was referred to the standard steam table (e.g., Steam Table, Japan Society of Mechanical Engineers, Tokyo, 25 November 1999).

Table 3. Averaged $\mathrm{CO}_{2} / \mathrm{H}_{2} \mathrm{O}$ molar ratio of volcanic gases with high temperature.

\begin{tabular}{cccccc}
\hline Volcano & & & & Temp & Reference \\
& Average & $1 \sigma$ & $n$ & ${ }^{\circ} \mathrm{C}$ & \\
\hline Colima & 0.016 & 0.006 & 10 & $>700$ & Taran et al. $(2002)$ \\
Kudriavy & 0.015 & 0.005 & 14 & $>900$ & Korzhinnsky et al. $(2002)$ \\
Momotombo & 0.025 & 0.010 & 47 & $>800$ & Menyailov et al. $(1986)$ \\
Usu & 0.018 & 0.009 & 18 & $>600$ & Ossaka et al. $(1984)$ \\
Unzen & 0.020 & 0.007 & 7 & $>700$ & Ohba et al. $(1994)$ \\
Satsuma-Iwojima & 0.0046 & 0.0012 & 8 & $>700$ & Shinohara et al. $(1993)$
\end{tabular}

and $\mathrm{SW}$ were to be vaporized, the $\mathrm{CO}_{2} / \mathrm{H}_{2} \mathrm{O}$ ratio would be much lower than that of the MV. The $\mathrm{CO}_{2} / \mathrm{H}_{2} \mathrm{O}$ ratio in MW and SW was assumed to be zero in Fig. 5, while the $\mathrm{CO}_{2} / \mathrm{H}_{2} \mathrm{O}$ ratio of $\mathrm{MV}$ was assumed to be 0.04 , so that the triangle regions defined by MV-MW-SW in Figs. 5 and 6 cover the points observed by Kazahaya et al. (1993). The $\mathrm{CO}_{2} / \mathrm{H}_{2} \mathrm{O}$ ratio of volcanic gas observed at several volcanoes is given in Table 3, where high-temperature gases were selected. Although the gas emitted by Satsuma Iwojima has an exceptionally low ratio, the ratio of the most of the volcanoes is restricted to less than 0.035 . The assumed value for Izu-Oshima, 0.04, is close to the highest ratio observed at the volcanoes presented in Table 3 .

Figure 5 shows the change in the $\mathrm{CO}_{2} / \mathrm{H}_{2} \mathrm{O}$ ratio and $\delta^{18} \mathrm{O}$ of $\mathrm{H}_{2} \mathrm{O}$ due to condensation. The change in the $\mathrm{CO}_{2} / \mathrm{H}_{2} \mathrm{O}$ ratio by condensation of $\mathrm{H}_{2} \mathrm{O}$ vapor is expressed by,

$$
C=C_{i} F^{\beta-1},
$$

where $C$ indicates the $\mathrm{CO}_{2} / \mathrm{H}_{2} \mathrm{O}$ ratio of fumarolic gas, and $\beta$ indicates the $\mathrm{CO}_{2} / \mathrm{H}_{2} \mathrm{O}$ distribution factor between $\mathrm{H}_{2} \mathrm{O}$ liquid and vapor, the numerical value of which is shown in Table 2. The observed fumarolic gases in this study are distributed along the condensation curves $\mathrm{C} 1, \mathrm{C} 2$, and $\mathrm{C} 3$, which represent initial mixtures of 4,10 , and $20 \%$ magmatic vapor, respectively. Notice that the fumarolic gases emitted at the $\mathrm{K}$ fumarole plot along $\mathrm{C} 3$. A high $\mathrm{CO}_{2} / \mathrm{H}_{2} \mathrm{O}$ ratio requires the fraction of $\mathrm{MV}$ to be as high as $20 \%$. In contrast, the low $\mathrm{CO}_{2} / \mathrm{H}_{2} \mathrm{O}$ ratio at the $\mathrm{X}-15$ fumerole requires $4-10 \%$ of mixing with $\mathrm{MV}$, a much lower mixing ratio relative to the fumarolic gas at $\mathrm{K}$. The distribution of observed fumarolic gases in Fig. 5 is also similar to the distribution shown in Fig. 6 where the $\mathrm{CO}_{2} / \mathrm{H}_{2} \mathrm{O}$ ratio is correlated with $\delta \mathrm{D}$. In Fig. 4 , the contribution of MV is about $10 \%$ for the fumarolic gases emitted at both $\mathrm{K}$ and $\mathrm{X}-15$.

In terms of the mixing ratio of $\mathrm{MV}$, the interpretation based on the correlation in Fig. 4 is inconsistent with that in Figs. 5 and 6, suggesting that a simple mixing between $\mathrm{MV}$ and $\mathrm{MW}$ and a subsequent condensation of $\mathrm{H}_{2} \mathrm{O}$ vapor can not explain the observed correlation among $\delta^{18} \mathrm{O}, \delta \mathrm{D}$, and the $\mathrm{CO}_{2} / \mathrm{H}_{2} \mathrm{O}$ ratio. 


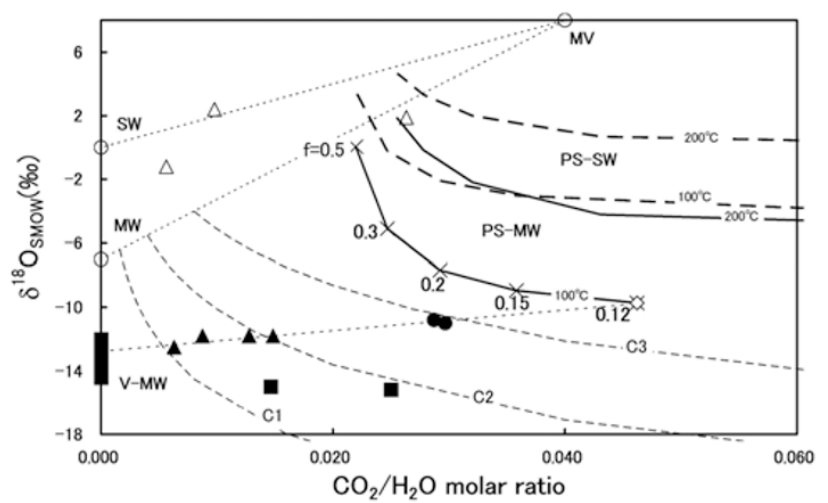

Fig. 5. Correlation between the $\delta^{18} \mathrm{O}$ of $\mathrm{H}_{2} \mathrm{O}$ and the $\mathrm{CO}_{2} / \mathrm{H}_{2} \mathrm{O}$ ratio of fumarolic gas with calculated primary steam and the end members producing the primary steam. See Fig. 4 for the definition of the symbols. Three of the data points by Kazahaya et al. (1993) are given only because the other data were not accompanied by the $\mathrm{CO}_{2} / \mathrm{H}_{2} \mathrm{O}$ ratio.

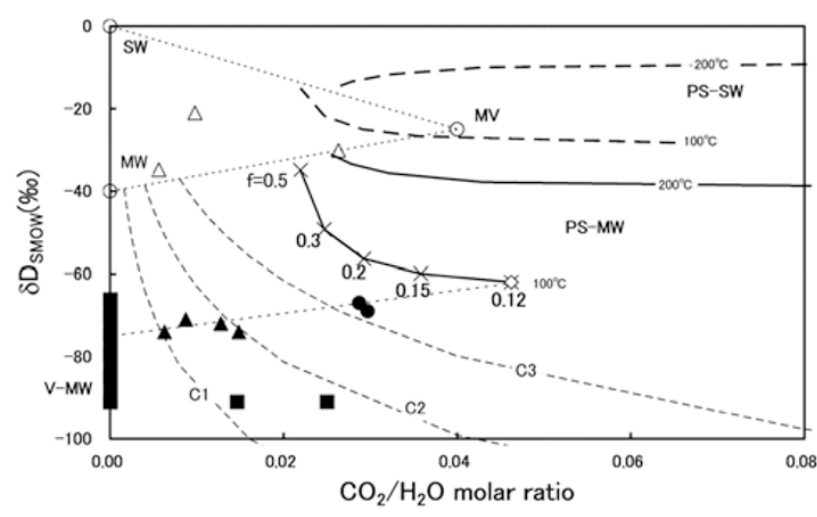

Fig. 6. Correlation between the $\delta \mathrm{D}$ of $\mathrm{H}_{2} \mathrm{O}$ and the $\mathrm{CO}_{2} / \mathrm{H}_{2} \mathrm{O}$ ratio of fumarolic gas with calculated primary steam and the end members producing the primary steam. See Fig. 4 for the definition of the symbols. Only three of the data points of Kazahaya et al. (1993) are given in the figure.

\subsection{Primary steam}

As described in the previous section, the correlation between the $\mathrm{CO}_{2} / \mathrm{H}_{2} \mathrm{O}$ ratio and stable isotope ratios can not be explained by direct mixing between $\mathrm{MV}$ and $\mathrm{MW}$ and a subsequent partial condensation of $\mathrm{H}_{2} \mathrm{O}$ vapor. I propose an alternative explanation based on three facts/observations: (1) thermal water was discharged from a bore hole on the northern middle flank of Izu-Oshima volcano; (2) the steam discharged with this thermal water contains $\mathrm{CO}_{2}$ gas of magmatic origin; (3) the concentration of $\mathrm{CO}_{2}$ in the steam has been affected by the volcanic activity of Izu-Ohshima (Shimoike and Notsu, 2000). In addition, the thermal water discharged from active volcanoes has been explained by a mixing of magmatic fluid and groundwater of meteoric origin (Henley and Ellis, 1983), and the origin of the fumarolic gas has been explained by the formation of steam, which was created by the mixing of MV and meteoric groundwater, based on stable isotope ratio of $\mathrm{H}_{2} \mathrm{O}$ (Giggenbach and Stewart, 1982). In this section, the observed fumarolic gas is modeled by the steam derived from MV and MW. A similar argument has been made by Taran et al. (1997) for the interpretation of boiling temperature fumarolic gas at Abacha volcano.

Following Giggenbach and Stewart (1982), the steam and the coexisting liquid generated by mixing between MV and MW is referred to as "Primary steam (PS)" and "Primary water (PW)", respectively. The $\mathrm{CO}_{2} / \mathrm{H}_{2} \mathrm{O}$ ratio and stable isotope ratio of PS can be estimated by solving the following equations.

$$
\begin{aligned}
& H_{\mathrm{MV}} f+H_{\mathrm{MW}}(1-f)=H_{\mathrm{PS}} g+H_{\mathrm{PW}}(1-g) \\
& \delta_{\mathrm{MV}} f+\delta_{\mathrm{MW}}(1-f)=\delta_{\mathrm{PS}} g+\delta_{\mathrm{PW}}(1-g) \\
& C_{\mathrm{MV}} f+C_{\mathrm{MW}}(1-f)=C_{\mathrm{PS}} g+C_{\mathrm{PW}}(1-g) \\
& \alpha=\frac{\delta_{\mathrm{PW}}+1000}{\delta_{\mathrm{PS}}+1000} \\
& \beta=\frac{C_{\mathrm{PW}}}{C_{\mathrm{PS}}}
\end{aligned}
$$

In Eq. (3), $H$ indicates the enthalpy of MV, MW, PS, and $\mathrm{PW}$, and $f$ and $g$ indicate the mixing fractions of MV and generating fraction of PS, respectively. In general, $g$ is not equal to $f$. Equations (3), (4) and (5) describe the conservation of enthalpy, isotope ratio, and $\mathrm{CO}_{2} / \mathrm{H}_{2} \mathrm{O}$ ratio $(C)$, respectively, during the mixing of fluids and the separation to PS and PW. Equations (6) and (7) describe the equilibrium between PS and PW in terms of stable isotopic fractionation and $\mathrm{CO}_{2}$ distribution. The numerical values used for calculating the $\mathrm{CO}_{2} / \mathrm{H}_{2} \mathrm{O}$ ratio and the stable isotope of PS are summarized in Table 2. Here I define PS-MW and PS$\mathrm{SW}$, which is the primary steam generated from the mixing of MV with MW and SW, respectively. The composition of PS-SW can be obtained in the same manner as that for PS-MW based on Eqs. (3)-(7), by substituting SW for MW.

Allowing freedom for the $f$ value, the $\mathrm{CO}_{2} / \mathrm{H}_{2} \mathrm{O}$ and stable isotope ratios of PS are expressed as the solid and dashed curves in Figs. 5 and 6. As the temperature of PS and $\mathrm{PW}$ is unknown, two cases were considered where the temperature was 100 and $200^{\circ} \mathrm{C}$, respectively. In Figs. 5 and 6 , the $\mathrm{CO}_{2} / \mathrm{H}_{2} \mathrm{O}$ ratio of PS increases and the isotope ratio decreases as $f$ decreases. At the left and right ends of the PS curve in Figs. 5 and 6 , the $f$ value is 0.5 and 0.12 , respectively, at $100^{\circ} \mathrm{C}$; at the left and right ends of the PS curve, the $f$ value is 0.6 and 0.2 , respectively, at $200^{\circ} \mathrm{C}$.

According to Kazahaya et al. (1993), heated groundwater of a meteoric origin existed in the volcanic body of Mt. Mihara. Here, a vapor phase equilibrated with the meteoric water at $50-100^{\circ} \mathrm{C}$ is introduced as $\mathrm{V}-\mathrm{MW}$. The range of the V-MW is shown in Figs. 5 and 6 on the lower part of the $y$-axis. The observed fumarolic gases at $\mathrm{K}$ and $\mathrm{X}-15$ are located between the V-MW and the right end of PS-MW curve at $100^{\circ} \mathrm{C}$ (diamond-shaped symbols). Therefore the high $\mathrm{CO}_{2} / \mathrm{H}_{2} \mathrm{O}$ ratio of the gas at $\mathrm{K}$ can be attributed to the large contribution of PS-MW at $100^{\circ} \mathrm{C}$. In Fig. 3, PS-MW at $100^{\circ} \mathrm{C}$ is represented by a line. The isotope ratios of the observed fumarolic gases are plotted between the diamond symbol and V-MW. By introducing the PS, the correlation between the $\mathrm{CO}_{2} / \mathrm{H}_{2} \mathrm{O}$ ratio and the stable isotope ratio of $\mathrm{H}_{2} \mathrm{O}$ can be explained consistently. In the above model, the condensation of $\mathrm{H}_{2} \mathrm{O}$ vapor is not necessary to explain the composition of the gases at $\mathrm{K}$ and $\mathrm{X}-15$. However, the low isotope ratio of gas at $\mathrm{A}$ requires a partial condensation 


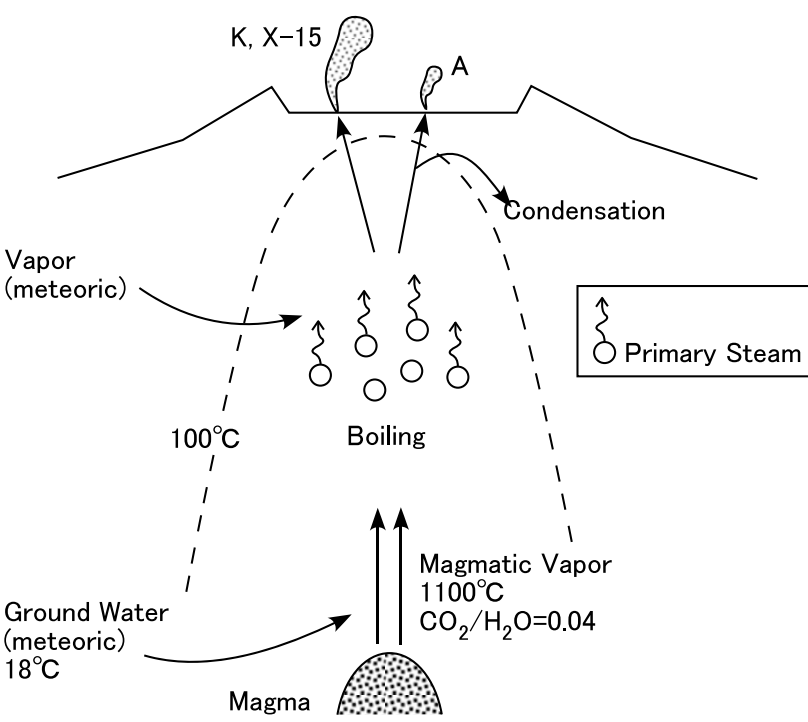

Fig. 7. Schematic view of the hydrothermal system generating the fumarolic gases. The dashed curve shows the isotherm of $100^{\circ} \mathrm{C}$.

of $\mathrm{H}_{2} \mathrm{O}$ vapor. Based on observations of the JMA, the outlet temperature of X-15 has been quite stable and has not shown any annual change. In the above model, the fumarolic gas at X-15 is a mixture of PS and V-MW. Both PS and V-MW would have a large heat capacity because they develop in a volcanic body. The stability of the outlet temperature at X-15 supports the above model for fumarolic gas formation.

The PS-MW at $200^{\circ} \mathrm{C}$ and PS-SW at both 100 and $200^{\circ} \mathrm{C}$ seems to be inappropriate for the end member of fumarolic gas because if those vapors are the end members, the mixing line connecting V-MW would have to have a steep positive slope in Figs. 5 and 6.

\section{Conclusions}

The formation of fumarolic gas is schematically described in Fig. 7. If we ignore the $\mathrm{CO}_{2} / \mathrm{H}_{2} \mathrm{O}$ ratio of the fumarolic gas, its formation might be explained by the direct mixing of $\mathrm{MV}$ and $\mathrm{MW}$ and a subsequent partial condensation of $\mathrm{H}_{2} \mathrm{O}$ vapor, based on $\delta \mathrm{D}$ and $\delta^{18} \mathrm{O}$ of $\mathrm{H}_{2} \mathrm{O}$. The observed $\mathrm{CO}_{2} / \mathrm{H}_{2} \mathrm{O}$ ratio in fumarolic gas has a large variation, which is difficult to explain based on the direct mixing of MV and MW.

The introduction of the primary steam component with a vapor phase originating in meteoric groundwater reproduces a gas phase whose isotope ratio is comparable to that of the observed fumarolic gas with variable $\mathrm{CO}_{2} / \mathrm{H}_{2} \mathrm{O}$ ratio. The interaction of magmatic fluid and meteoric groundwater and the subsequent formation of steam, as shown in this study, is one of the features common to volcanic hydrothermal systems (Henley and Ellis, 1983).

Acknowledgments. I would like to sincerely thank Dr. T. Fischer and Dr. Y. Taran for their detailed reviewing the manuscript, which significantly improved the content of paper. I also thank Dr. A. Takada for his editorial handling of this paper. The support by Mr. T. Sawa, Mr. N. Taira, Mr. A. Shimizu and Mr. Y. Kakuage with the sampling of fumarolic gases is acknowledged.

\section{References}

Coleman, M. L., T. J. Shepherd, J. J. Durham, J. E. Rouse, and G. R. Moore, Reduction of water with zinc for hydrogen isotope analysis, Anal. Chem., 54, 993-995, 1982.

Conway, E. J., Microdiffusion analysis and volumetric error, 3rd edn., Crosby-Lockwood, London, 1950.

Epstein, S. and T. K. Mayeda, Variation of ${ }^{18} \mathrm{O}$ content of waters from natural sources, Geochim. Cosmochim. Acta, 4, 213-224, 1953.

Fujii, T., S. Aramaki, T. Kaneko, K. Ozawa, Y. Kawanabe, and T. Fukuoka, Petrology of the lava and ejecta of the November, 1986 eruption of IzuOshima volcano, Bull. Volcanol. Soc. Jpn., 33, S234-S254, 1988 (in Japanese with English abstract).

Giggenbach, W. F., A simple method for the collection and analysis of volcanic samples, Bull. Volcanol., 39, 132-145, 1975.

Giggenbach, W. F., Geothermal gas equilibria, Geochim. Cosmochim. Acta, 44, 2021-2032, 1980.

Giggenbach, W. F., Isotopic shifts in waters from geothermal and volcanic systems along convergent plate boundaries and their origin, Earth Planet. Sci. Lett., 113, 495-510, 1992.

Giggenbach, W. F. and M. K. Stewart, Processes controlling the isotopic composition of steam and water discharges from steam vents and steamheated pools in geothermal areas, Geothermics, 11, 71-80, 1982.

Henley, R. W. and A. J. Ellis, Geothermal systems ancient and modern: A geochemical review, Earth Sci. Rev., 19, 1-50, 1983.

Horita, J. and D. J. Wesolowski, Liquid-vapor fractionation of oxygen and hydrogen isotopes of water from the freezing to the critical temperature, Geochim. Cosmochim. Acta, 58, 3425-3437, 1994.

Kawanabe, Y., Geological map of Izu-Oshima volcano. Geological map of volcanoes, Geological Survey of Japan, 1998.

Kazahaya, K., M. Takahashi, and A. Ueda, Discharge model of fumarolic gases during post-eruptive degassing of Izu-Oshima volcano, Japan, Geochem. J., 27, 261-270, 1993.

Korzhinsky, M. A., R. E. Botcharnikov, S. I. Tkachenko, and G. S. Steinberg, Decade-long study of degassing at Kudriavy volcano, Iturup, Kurile Islands (1990-1999): Gas temperature and composition variations, and occurrence of 1999 phreatic eruption, Earth Planets Space, 54, 337-347, 2002.

Menyailov, I. A., L. P. Nikitina, V. N. Shapar, and V. P. Pilipenko, Temperature increase and chemical change of fumarolic gases at Momotombo volcano, Nicaragua, in 1982-1985: Are these indicators of a possible eruption?, J. Geophys. Res., 91, 12199-12214, 1986.

Notsu, K., T. Mori, S. C. DoVale, H. Kagi, and T. Ito, Monitoring quiescent volcanoes by diffuse $\mathrm{CO}_{2}$ degassing: Case study of Mt. Fuji, Japan, Pure Appl. Geophys., 163, 825-835, 2006.

Ohba, T., J. Hirabayashi, and M. Yoshida, Equilibrium temperature and redox state of volcanic gas at Unzen volcano, Japan, J. Volcanol. Geotherm. Res., 60, 263-272, 1994.

Ossaka, J., J. Hirabayashi, and T. Ozawa, Chemical compositions of volcanic gases collected after the 1977 eruption of Usu volcano. Joint geophysical and geochemical observations: Usu volcano (SeptemberDecember, 1982) and Tarumai volcano (September-October, 1983), 117-126, 1984 (in Japanese).

Ozawa, T., Chemical analysis of volcanic gases: I. Chemical analysis of volcanic gases containing water vapor, hydrogen chloride, sulfur dioxide, hydrogen sulfide, carbon dioxide, etc., Geochem. Int., 5, 939-947, 1968.

Sano, Y. and B. Marty, Origin of carbon in fumarolic gas from island arcs, Chem. Geol., 119, 265-274, 1995.

Sano, Y., T. Gamo, K. Notsu, and H. Wakita, Secular variations of carbon and helium isotopes at Izu-Oshima volcano, Japan, J. Volcanol. Geotherm. Res., 64, 83-94, 1995.

Sawa, T., T. Ohba, and J. Hirabayashi, The hydrothermal system beneath Ohwakudani on Hakone volcano, Japan: Traced by stable isotope ratio of $\mathrm{H}_{2} \mathrm{O}$, J. Nucl. Sci. Technol., 43, 468-473, 2006.

Shimoike, Y. and K. Notsu, Continuous chemical monitoring of volcanic gas in Izu-Oshima volcano, Japan, J. Volcanol. Geotherm. Res., 101, 211-221, 2000.

Shinohara, H., W. F. Giggenbach, K. Kazahaya, and J. W. Hedenquist, Geochemistry of volcanic gases and hot springs of Satsuma-Iwojima, Japan: Following Matsuo, Geochem. J., 27, 271-285, 1993.

Suwa, A. and Y. Tanaka, The changes in the temperautres of the fumaroles in the crater of Miharayama, Oshima, in connection with the activities of the volcano, Bull. Volcanol. Soc. Japan, 13, 107-118, 1959.

Takahashi, M., K. Abe, T. Noda, K. Kazahaya, N. Ando, and T. Soya, Koshimizu thermal spring formed in the 1986 eruption of Izu Oshima 
volcano, J. Balneological Soc. Jpn., 49, 176-185, 2000 (in Japanese with English abstract).

Taran, Y. A., B. G. Pokrovskiy, and Y. M. Dubik, Isotope composition and origin of water in andesite magma, Trans. USSR Acad. Sci., 304, 199202, 1990.

Taran, Y., C. B. Connor, V. N. Shapar, A. A. Ovsyannikov, and A. A Bilichenko, Fumarolic activity of Avachinsky and Koryaksky volcanoes, Kamchatka, from 1993 to 1994, Bull. Volcanol., 58, 441-448, 1997.

Taran, Y., A. Bernard, J. C. Gavilanes, E. Lunezheva, A. Cortes, and M. A. Armienta, Chemistry and mineralogy of high-temperature gas discharges from Colima volcano, Mexico. Implications for magmatic gas? atmosphere interaction, J. Volcanol. Geotherm. Res., 108, 245-264, 2001.

Taran, Y., J. C. Gavilanes, and A. Cortes, Chemical and isotopic composition of fumarolic gases and the $\mathrm{SO}_{2}$ flux from Volcan de Colima, Mexico, between the 1994 and 1998 eruptions, J. Volcanol. Geotherm. Res., 117, 105-119, 2002.

T. Ohba (e-mail: ohba@ksvo.titech.ac.jp) 